\title{
Determination of Polyphenols and Anti-Inflammatory Activity of Aqueous and Ethanolic Extracts of Erythroxylum Emarginatum (Erythroxylaceae)
}

\author{
Kouakou Kouakou Victor ${ }^{1,5^{*}}$, Opkekon Aboua Timothee. ${ }^{2}$, \\ Kouakou - Siransy Gisele ${ }^{3}$, Yapi Houphouet Felix ${ }^{1}$, Gbassi Komenan Gildas ${ }^{4,5}$ \\ ${ }^{\text {I}}$ Pharmacodynamics Biochemical Laboratory, UFR Biosciences, Felix Houphouet Boigny University. PO Box, \\ 582, Abidjan 22-Côte d'Ivoire \\ ${ }^{2}$ Organic Chemistry Laboratory and Natural Substances, UFR Sciences of Structures of Matter and Technology, \\ Felix Houphouet Boigny University. PO Box, 582, Abidjan 22- Côte d'Ivoire \\ ${ }^{3}$ Pharmacology Laboratory, UFR Pharmaceutical and Biological Sciences, Felix Houphouet Boigny University. \\ PO Box, 582, Abidjan 22- Côte d'Ivoire \\ ${ }^{4}$ Analytical Chemistry Laboratory, UFR Pharmaceutical and Biological Sciences, Felix Houphouet Boigny \\ University. PO Box, 582, Abidjan 22- Côte d'Ivoire \\ ${ }^{5}$ National Laboratory of Public Health, PO Box, 1803 Abidjan 18 - Côte d'Ivoire
}

\begin{abstract}
Our work was part of the search for new active molecules in the inflammatory process to relieve pain more effectively. Erythroxylum emarginatum is a plant distributed in tropical regions of South America, Africa, and Madagascar. The phytochemical screening has shown that the bark of stems contained more full of polyphenols than the leaves. Erythroxylum emarginatum is known for its anti-inflammatory properties, its use in the treatment of bronchial affections and especially during asthma. The comparative study of Erythroxylum emarginatum bark of stems aqueous and ethanolic extracts with diclofenac on induced inflammation of rat paw by carrageenan revealed anti-inflammatory properties of both extracts.

In effect at doses of $200 \mathrm{mg} / \mathrm{kg}$ of body weight, both extracts have anti-inflammatory properties comparable to those of diclofenac dosed at $25 \mathrm{mg} / \mathrm{kg}$ body weight. These results would justify the use of Erythroxylum emarginatum bark of stems by people to prevent inflammatory processes in arthritis and asthma.
\end{abstract}

Keywords: Anti-inflammatory, Erythroxylum emarginatum, extract, polyphenols.

\section{Introduction}

Erythroxylum emarginatum is a shrub or small tree of six (6) meters high, distributed in tropical regions of South America, Africa, and Madagascar. The leaves are alternate, oblanceolate, and elliptical. The flowers are in small axillary clusters, white, fragrant. The fruit is a drupe ellipsoid, fleshy and red ${ }^{[10]}$. The decoction of leaves is used to treat asthma, arthritis and influenza and kidney problems and reproduction ${ }^{[4]}$. The leaves and roots of the plant are used to relieve pain. In general, this plant is known for its anti-inflammatory properties and its use in the treatment of bronchial and respiratory affections ${ }^{[3]}$. This study focuses on the determination of polyphenols in the leaves and bark of stems and pharmacological properties of aqueous and ethanolic extracts of Erythroxylum emarginatum to found a scientific basis for its use ${ }^{[12]}$. This study aims to verify the use of Erythroxylum emarginatum as anti-inflammatory remedy.

\section{Collection of plant material}

\section{Materials And Methods}

The bark of stems and the leaves of Erythroxylum emarginatum were collected to Kami on 2013 in the region of Bouaflé, a city situated in the western center of Côte d'ivoire. After identifying at the National Floristic Center at the Félix Houphouët Boigny University, these plant parts were dried at room temperature for two weeks and sprayed with an electric grinder type IKA- MAG®.

\section{Preparation of extracts}

The extracts were prepared according to the extraction method used by Guédé-Guina et al. $(1993)^{[5]} .1$ liter of distilled water was added in 100 grams of the bark of stems powder. The obtained mixture was homogenized by means of a magnetic agitator during 24 hours. The homogenate was filtered successively twice on some cotton wool and then once on Whatman paper185 millimeters of diameter. The collected filtrate was put in steam room at $500^{\circ} \mathrm{C}$. The obtained powder constituted the aqueous extract used for the preparation of the various concentrations of products. The ethanolic extract was prepared in the same way as the aqueous extract but by using $700 \mathrm{ml}$ of ethanol and $300 \mathrm{ml}$ of water. The various concentrations of aqueous and ethanolic 
extracts of Erythroxylum emarginatum were prepared according to the body weight (b. wt.) of the rats and the amount of product to be injected expressed in $\mathrm{mg} / \mathrm{kg} \mathrm{b}$.wt. and the amount of extract to be injected is $100 \mathrm{mg}$ to $1000 \mathrm{~g}$ b.wt. of animal and the volume of solution to be injected is $1 \mathrm{ml}$ per animal ${ }^{[11]}$.

\section{Animal material}

The experimental animals used were Wistar rats of average weight $90 \pm 0.31$ grams and aged 10 weeks supplied by the pet shop of the Superior teachers training college (ENS) of the Félix Houphouët Boigny University. The rats were placed in plastic cages containing shavings of wood renewed every 3 days. They were transferred and acclimatized during approximately 4 weeks to the pet shop of the pharmaceutical and biological sciences department of Félix Houphouet Boigny University.

\section{Determination of polyphenols in the bark of stems and leaves of Erythroxylum emarginatum}

The determination of polyphenols in the bark of stems and leaves was made according to the FolinCiocalteu colorimetric method described by Mahmoudi et $a l^{[8]}$ with modifications that said at $0.1 \mathrm{ml}$ extract of Erythroxylum emarginatum (bark or leaves) are mixed $0,5 \mathrm{ml}$ of $2 \mathrm{~N}$ Folin-Ciocalteu reagent, $1 \mathrm{ml}$ of water and $3 \mathrm{ml}$ of sodium carbonate $(\mathrm{Na} 2 \mathrm{CO} 3)$ to $7.5 \%(\mathrm{w} / \mathrm{v})$. The mixture was stirred and incubated in the dark room temperature for 10 minutes and centrifuged at $3000 \mathrm{rpm} / \mathrm{min}$ for 15 minutes and the absorbance was measured at $750 \mathrm{~nm}$ by UV spectrophotometer brand SPECORD ${ }^{\circledR} 210$ PLUS analytikjena. The calibration curve of gallic acid is obtained using various concentrations of standards ranging from 0 to $350 \mathrm{mg} / \mathrm{l}$ of gallic acid solution prepared in methanol in the same analysis conditions. The results are expressed in milligrams gallic acid equivalent per gram (EAG mg/g) of plant dry material ${ }^{[2]}[5]$.

\section{Determination of anti-inflammatory activity}

\subsection{Induction of edema with carrageenan $1 \%$}

The rats were divided into 6 groups of 6 , were fasted for 16 hours before experimentation. We measured for each rat the initial diameter (Do) of the right hind paw. The different groups of rats received by intraperitoneal route:

- $\quad$ Group1: physiological saline solution $(\mathrm{NaCl} 0.9 \%)$;

- Group 2 and 3: respectively 100 and $200 \mathrm{mg} / \mathrm{kg}$ b.wt. of the bark of stems aqueous extract of Erythroxylum emarginatum;

- $\quad$ Group 4 and 5: respectively 100 and $200 \mathrm{mg} / \mathrm{kg}$ b.wt. of the bark of stems ethanolic extract of Erythroxylum emarginatum and

- $\quad$ Group 6: Diclofenac sodium at a dose $25 \mathrm{mg} / \mathrm{kg}$ b.wt. (reference molecule).

One hour after these injections, $0.2 \mathrm{ml}$ of carrageenan $1 \%$ solution was injected into the subplanter region of right hind paw of each rat to induce edema ${ }^{[6]}$. The evolution of the edema of the right hind paw was determined at $1 \mathrm{~h}, 2 \mathrm{~h}, 3 \mathrm{~h}, 4 \mathrm{~h}, 5 \mathrm{~h}, 6 \mathrm{~h}$ and $24 \mathrm{~h}$ after carrageenan injection using a Digital Caliper (digital paw edema meter) ${ }^{[1]}$. The importance of the edema was determined by the increase in the diameter of the rat paw inflammation and percentages calculated as follows:

INF \% $=[$ Diameter of paw at time T - Initial diameter (Do) $] /$ Initial diameter (Do) x100

The anti-inflammatory activity was assessed by calculating the inhibition percentage of edema (\% INH) ${ }^{[9]}$. $\% \mathrm{INH}=[\%$ Control Diameter -\% Treaty Diameter $] / \%$ x100 Control Diameter.

\subsection{Determination of C - Reactive Protein (CRP)}

The rats were divided into 5 groups of 6 (all confused sex), blood was collected on the first day of the experiment $\left(\mathrm{D}_{0}\right)$.

The various groups of rats received by intraperitoneal route:

- Group 1: $200 \mathrm{mg} / \mathrm{kg}$ b.wt. of aqueous extract of Erythroxylum emarginatum;

- $\quad$ Group 2: $200 \mathrm{mg} / \mathrm{kg}$ b.wt. of Erythroxylum emarginatum ethanol extract;

- $\quad$ Group 3: Sodium Diclofenac 25mg/kg b.wt.;

- Group 4: $\mathrm{NaCl}$ saline solution $(0.9 \%)$ and

- $\quad$ Group 5 received nothing.

One hour after these injections, $0.2 \mathrm{ml}$ of the carrageenan solution at $1 \%$ was injected into the subplanter region of right hind paw of each rat to induce edema, excepted the rats of group 5 (control group).

The values of C-reactive protein (CRP) were measured $5 \mathrm{~h}$ after infection of carrageenan. The rats were anesthetized with Ether solution (COOPER ${ }^{\circledR}$ ) and blood collection was carried out through the tail vein of rats to preserve their lives and prevent suffering. The collected blood was sent to the laboratory for biological analysis. 
At laboratory the collected blood was centrifuged at $4000 \mathrm{rpm}$ for 10 minutes and serum was collected for the determination of CRP. CRP was measured by ELISA (Enzyme-Linked Immunosorbent Assay) using the anti-CRP mouse antibody reagents provided by the $\mathrm{ABCAM}^{\circledR}$ laboratories.

\section{Results And Discussion}

1. Determination of polyphenols in the bark of stems and leaves extracts of Erythroxylum emarginatum

The optical densities (OD) measured after reading the samples to UV spectrophotometer were 0.557 $\mathrm{nm}$ for the bark of stems extracts and $0.089 \mathrm{~nm}$ for leaves extracts. The equation of the calibration curve used was: $\mathrm{y}=0.0014 \mathrm{x}+0.0109$ where $\mathrm{y}$ represented absorbance and $\mathrm{x}$ the gallic acid concentration (Fig. 1).

Our study demonstrated that the Erythroxylum emarginatum bark of stems extract is richer in polyphenols than the leaves. Indeed the amount of polyphenols in 2 grams of powder is $390.071 \mathrm{mgEAG} / \mathrm{g}$ for bark of stems against $55.785 \mathrm{mgEAG} / \mathrm{g}$ for the leaves. We therefore focused our choice on the bark of stems for assessing anti-inflammatory activity.

\section{Anti-inflammatory activity}

The carrageenan $1 \%$ induced edema which gradually increased to a maximum of $6.10 \mathrm{~mm}$ compared to the initial diameter rat paw $(4.21 \mathrm{~mm})$ (Fig.3)(Table1). The administration of diclofenac dosed at $25 \mathrm{mg} / \mathrm{kg}$ prevented significantly increasing the diameter of the rat paw which varies from $4.42 \mathrm{~mm}$ to $5.35 \mathrm{~mm}$ after injection of carrageenan(Fig.3)(Table1).

The administration of aqueous extracts $100,200 \mathrm{mg} / \mathrm{kg}$ b.wt. and ethanolic $100,200 \mathrm{mg} / \mathrm{kg}$ b.wt. significantly prevents acute paw edema in rats after 24 hours; however, the aqueous extract is more effective in the prevention of acute paw edema of rats. The aqueous extract $200 \mathrm{mg} / \mathrm{kg}$ had significantly similar percentage of inhibition $(\mathrm{P}<0.05)$ than that of diclofenac (Fig.4) (Table 2).

The CRP value of the group $4(\mathrm{NaCl}+$ carrageenan) was significantly higher $(\mathrm{P}<0.05)$ compared to other groups tested (aqueous extracts $200 \mathrm{mg} / \mathrm{kg}$ b.wt., ethanolic extracts $200 \mathrm{mg} / \mathrm{kg}$ b.wt., diclofenac $25 \mathrm{mg} / \mathrm{kg}$ b.wt., and the control). The difference between the results obtained with aqueous extracts $200 \mathrm{mg} / \mathrm{kg} \mathrm{b}$.wt., extracts ethanolic $200 \mathrm{mg} / \mathrm{kg}$ b.wt., diclofenac $25 \mathrm{mg} / \mathrm{kg}$ b.wt., and control ( $\mathrm{NaCl}$ single) is not significant $(\mathrm{P}>$ 0.05 ) between them (Fig.5).

The CRP testing has confirmed the effectiveness of the aqueous extracts $200 \mathrm{mg} / \mathrm{kg}$ b.wt. and ethanolic $200 \mathrm{mg} / \mathrm{kg}$ b.wt. in the prevention of acute rat paw edema induced by carrageenan $1 \%$.

\section{Figures And Tables}

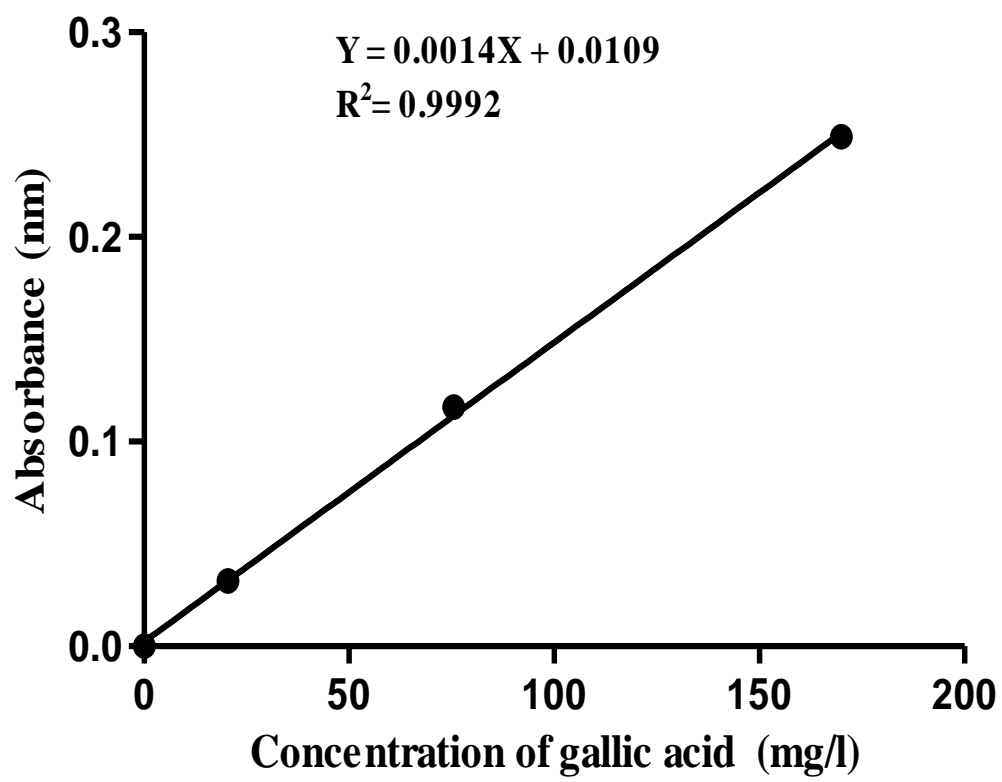

Fig 1 : Calibration curve of gallic acid 


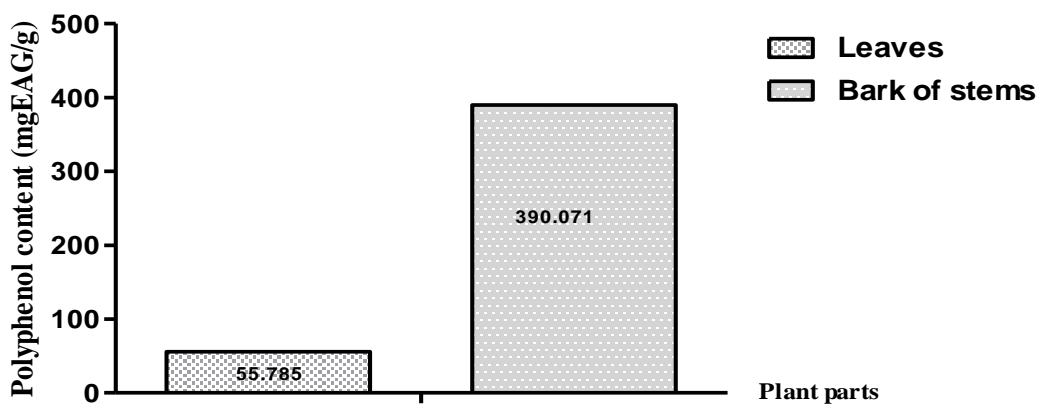

Fig 2 : Polyphenols content in the bark of stems and leaves extracts of Erythroxylum emarginatum

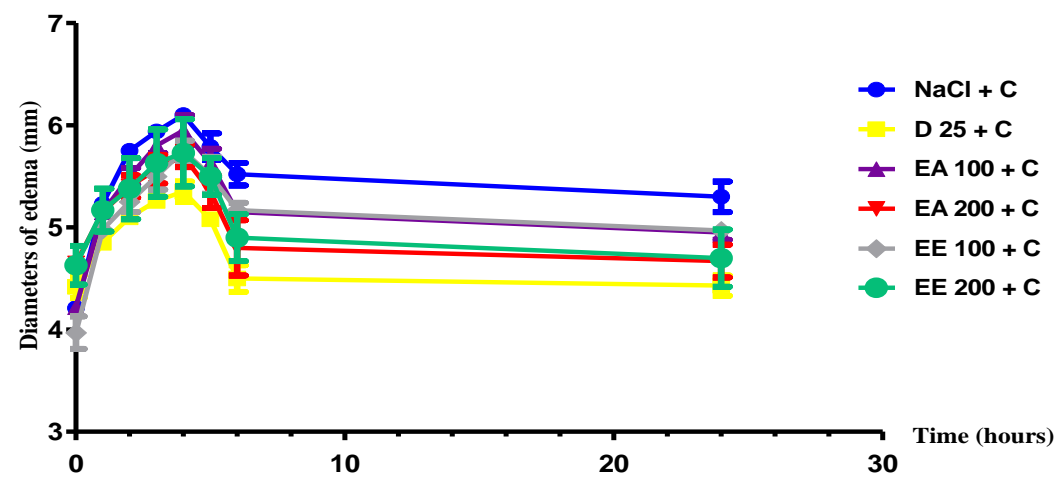

Fig.3 : Effects of aqueous and ethanolic extracts of Erythoxylum emaginatum and diclofenac on the diameters of the rat paw

$\mathrm{NaCl}+\mathrm{C}: \mathrm{NaCl}+$ Carrageenan

D 25 + C : Diclofenac 25mg/kg + Carrageenan

EA $100+\mathrm{C}$ : Aqueous Extract 100mg/kg + Carrageenan

EA 200 + C : Aqueous Extract 200mg/kg + Carrageenan

EE $100+\mathrm{C}:$ Ethanolic Extract $100 \mathrm{mg} / \mathrm{kg}+$ Carrageenan

EE $200+C$ : Ethanolic Extract $200 m g / k g+C a r r a g e e n a n$

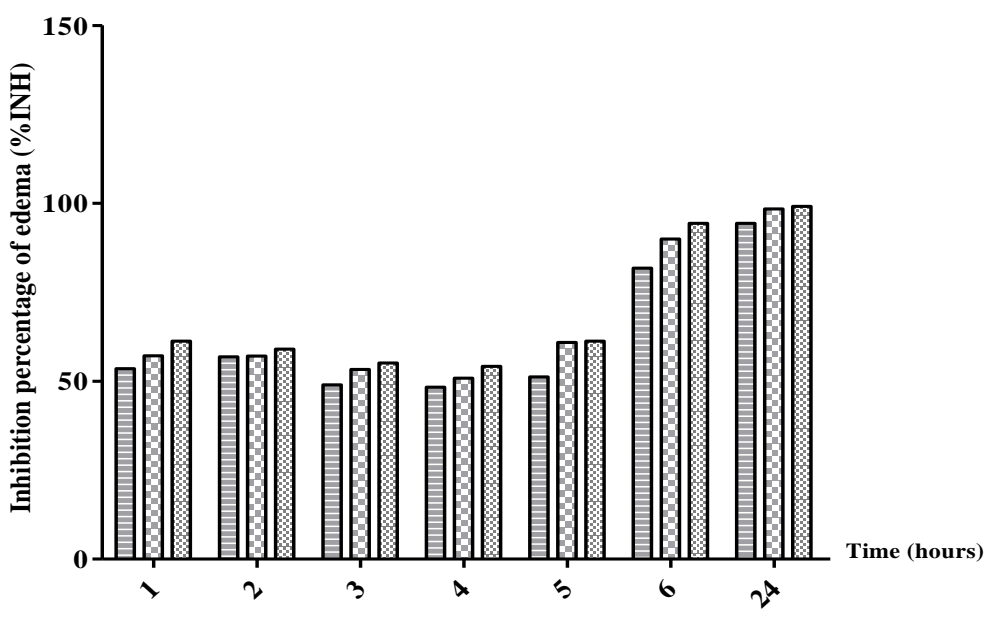

Fig.4 : Inhibition of edema induced by carrageenan in rat treated with aqueous and ethanolic extracts of Erythoxylum emarginatum and diclofenac

EE 200 : Ethanolic Extract 200mg/kg

EA 200 : Aqueous Extract $200 \mathrm{mg} / \mathrm{kg}$

D 25 : Diclofenac 25mg/kg 


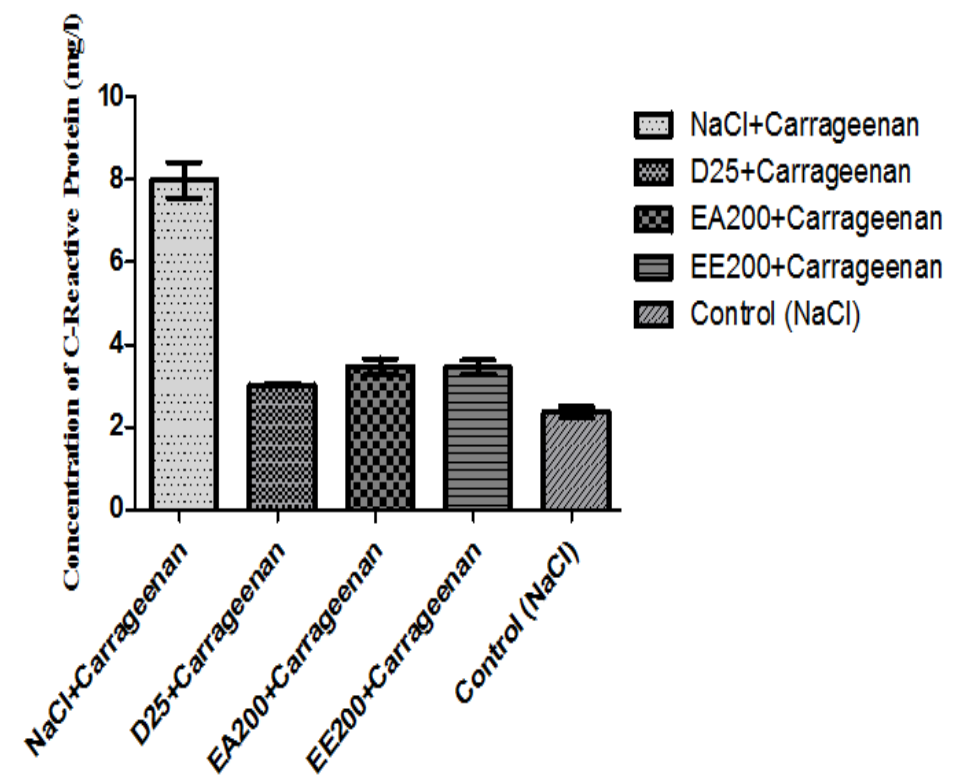

Fig 5 : Effect of aqueous and ethanolic extracts of Erythroxylum emargtnatumn on the concentration of C-Reactive Protein 5 hours after injection of carrageenan

Table 1: Effect of Erythroxylum emarginatum bark of stems extracts on carrageenan induced paw edema in rats

\begin{tabular}{|c|c|c|c|c|c|c|c|c|}
\hline & \multicolumn{8}{|c|}{ Edema diameter $(\mathrm{mm})$} \\
\hline $\begin{array}{c}\text { Treatment } \\
\text { groups }(n=6)\end{array}$ & $\mathbf{0 h}$ & $1 \mathrm{~h}$ & $2 h$ & 3h & $4 h$ & $5 \mathrm{~h}$ & $6 h$ & $24 \mathrm{~h}$ \\
\hline $\mathrm{NaCl}$ & $4.21 \pm 0.06$ & $5.23 \pm 0.02$ & $5.75 \pm 0.07$ & $5.94 \pm 0.05$ & $6.10 \pm 0.05$ & $5.79 \pm 0.13$ & $5.52 \pm 0.11$ & $5.30 \pm 0.15$ \\
\hline D 25 & $4.42 \pm 0.11$ & $4.85 \pm 0.05$ & $5.10 \pm 0.01$ & $5.26 \pm 0.07$ & $5.35 \pm 0.10$ & $5.08 \pm 0.03$ & $4.50 \pm 0.13$ & $4.43 \pm 0.10$ \\
\hline AQ 100 & $4.22 \pm 0.05$ & $5.15 \pm 0.02$ & $5.50 \pm 0.08$ & $5.80 \pm 0.07$ & $5.95 \pm 0.15$ & $5.63 \pm 0.14$ & $5.15 \pm 0.05$ & $4.95 \pm 0.07$ \\
\hline AQ 200 & $4.65 \pm 0.05$ & $5.15 \pm 0.04$ & $5.40 \pm 0.11$ & $5.57 \pm 0.14$ & $5.70 \pm 0.11$ & $5.35 \pm 0.16$ & $4.80 \pm 0.27$ & $4.67 \pm 0.16$ \\
\hline ETH 100 & $3.97 \pm 0.16$ & $4.98 \pm 0.04$ & $5.25 \pm 0.10$ & $5.50 \pm 0.13$ & $5.75 \pm 0.10$ & $5.51 \pm 0.18$ & $5.17 \pm 0.07$ & $4.97 \pm 0.06$ \\
\hline ETH 200 & $4.63 \pm 0.19$ & $5.17 \pm 0.21$ & $5.38 \pm 0.30$ & $5.63 \pm 0.33$ & $5.73 \pm 0.33$ & $5.50 \pm 0.18$ & $4.90 \pm 0.23$ & $4.70 \pm 0.28$ \\
\hline
\end{tabular}

AQ 100: Aqueous extract (100mg/kg b. wt.), AQ 200: Aqueous extract (200mg/kg b. wt.), ETH 100: Ethanolic extract (100mg/kg b. wt.), ETH 200: Ethanolic extract (200mg/kg b. wt.), D 25: Diclofenac $(25 \mathrm{mg} / \mathrm{kg}$ b. wt.), each value is Mean \pm SEM $N=6$ rats, $p<0.05$, One way ANOVA followed by Dunnet multiple comparison test, statistically no significant when compared to control $(\mathrm{NaCl})$.

Table 2: Percentage of inhibition of aqueous and ethanolic bark of stems extracts of Erythroxylum emarginatum on rat paw edema induced by carrageenan

\begin{tabular}{|c|c|c|c|c|c|c|c|c|}
\hline \multirow[t]{2}{*}{ Treatment } & \multicolumn{7}{|c|}{ Percentage of Inhibition (\%) } & \multirow{2}{*}{$\begin{array}{c}\text { Mean of } \\
\text { inhibition }(\%)\end{array}$} \\
\hline & $1 \mathrm{~h}$ & $2 \mathbf{h}$ & 3h & $4 h$ & $5 h$ & 6h & $24 h$ & \\
\hline $\mathrm{NaCl}$ (Control) & - & - & - & - & - & - & - & - \\
\hline Diclofenac & 61.29 & 59.04 & 55.12 & 54.19 & 61.23 & 94.38 & 99.17 & $69.20 \pm 7.21$ \\
\hline AQ 200 & 57.18 & $\mathbf{5 7 . 0 7}$ & 53.28 & 50.83 & 60.91 & 89.95 & 98.39 & $66.80 \pm 7.22$ \\
\hline ETH 200 & 53.56 & 56.88 & 49.00 & 48.29 & 51.20 & 81.80 & 94.36 & $62.16 \pm 6.91$ \\
\hline
\end{tabular}

\section{Conclusion}

This work has shown that the bark of stems of Erythroxylum emarginatum contained more polyphenols than the leaves, allowing us to choose the bark of stems for the evaluation of anti-inflammatory activity. The bark of stems aqueous and ethanolic extracts of Erythroxylum emarginatum showed efficacy in the prevention of acute edema of the rat paw induced by carrageenan $1 \%$. At doses of $200 \mathrm{mg} / \mathrm{kg}$ b.wt., these extracts have anti-inflammatory properties comparable to those of diclofenac dosed at $25 \mathrm{mg} / \mathrm{kg} \mathrm{b}$.wt. These results support the use of Erythroxylum emarginatum bark of stems by people to prevent inflammatory processes in arthritis and asthma.

\section{Ethical Approval}

The experimental procedures and protocols used in this study were approved by the Ethical Committee of Health Sciences, Felix Houphouet-Boigny University. These guidelines were in accordance with the 
European Council Legislation 87/607/EEC for the protection of experimental animals. All efforts were made to minimize animal suffering and reduce the number of animals used.

\section{References}

[1]. Anupama A, Kishor N, Rahul D \& Kanchan S, Evaluation of Anti-inflammatory and Analgesic Activities of Tamarindus indica Seeds, International Journal of Pharmaceutical Sciences and Drug Research, 4(3), 2012, 213-217.

[2]. Atanasova M \& Ribarova F, Phénols et flavonoïdes totaux dans les extraits secs des feuilles des bouleaux argentés bulgares (Betula pendula), Revue de génie industriel 4, 2009, 21-25.

[3]. Bisset J, Árboles de Cuba. Ed. Científico-Técnica, La Habana, Cuba, 1988, 146-149.

[4]. De Wet H, Antibacterial activity of the five South African Erythroxylaceae species. African Journalof Biotechnology, 10 (11), 2011, 511-514.

[5]. Guede-guina F, Vangah-manda M, Harouna D and Bahi C, Potencies of MISCA, a plant source concentrates against Fungi. Mycol. Med., 5(4), 1993, 225-229.

[6]. Kholkhal F, Lazouni H A, Bendahou M, Boublenza I, Chabane S D \& Chaouch T, Étude phytochimique et évaluation de l'activité anti-oxydante de Thymus Ciliatus ssp. Coloratus Afrique SCIENCE, 9 (1), 2013, $151-158$.

[7]. Mahanta B. \& Kalita J. (2012). Efficacy of Solanum torvum (Berries) on carrageenan induced rat paw edema model an in-vivo antiinflammatory study, International research journal of pharmacy, 3 (1), 2012, 232 - 234.

[8]. Mahmoudi S, Khali M \& Mahmoudi N, Etude de l'extraction des composés phénoliques de différentes parties de la fleur d'artichaut (Cynaras colymus L.), Revue «Nature \& Technologie ». B-Sciences Agronomiques et Biologiques, 9, 2012, 35-40.

[9]. Ndiaye M, SY G, Dièye AM, Touré MT \& Faye B, Evaluation de l'activité anti-inflammatoire de feuilles d'annona reticulata (annonaceae) sur l'œdème aigu de la patte de rat induit par la carragénine, Pharm. Méd. Trad. Afr., Vol. XIV, 2006, 179-186.

[10]. Nishiyama Y, Tropane alkaloids from Erythroxylum emarginatum, Journal of Naturals Medicines, 61, 2007, 56-58.

[11]. OCDE 423, (2001). Ligne directrice pour les essais de produits chimiques. Toxicité aigüe, Méthode par classe de toxicité aigüe.

[12]. Soro TY, Néné-bi, Zahoui OS, Yapi A \& Traoré F, Activité anti-inflammatoire de l'extrait aqueux de Ximenia americana (Linné) (olacaceae), journal of Animal \& Plant Sciences, 24(3), 2015, 3802-3813. 